\title{
DIATOM-BASED WATER QUALITY ASSESSMENT IN STREAMS INFLUENCE BY URBAN POLLUTION: EFFECTS OF NATURAL AND TWO SELECTED ARTIFICIAL SUBSTRATES, SÃO CARLOS-SP, BRAZIL
}

\author{
Bere, T. $^{1^{*}} \&$ Tundisi, J. G. ${ }^{1,2}$ \\ 1 - Instituto Internacional de Ecologia, Rua Bento Carlos, no 750, Centro, São Carlos, SP, CEP 13560- \\ 660; 2 - tundisi@iie.com.br \\ *Corresponding author: taubere@yahoo.com
}

\begin{abstract}
Braz. J. Aquat. Sci. Technol. 15(1): 54-63. ISSN 1983-9057. Diatoms are good indicators of water quality in lotic systems. The purpose of this study was to provide information about the effects of natural and artificial substrates on diatom-based water quality assessment. Two artificial substrates (bricks and glass) were placed at 6 sampling sites and left for a month during summer base-flow period (2008). Water quality variables were measured at the beginning and end of the experiment. The IndVal method was used to find indicator species and species assemblages characterizing the three substrates. Species richness, diversity and equitability differed among sampling sites, tending to be higher in relatively unpolluted compared to polluted sites. The relatively less polluted upstream sites were characterized by such species as Aulacoseira ambigua, Aulacoseira granulata, Cymbopleura naviculiformis, Eunotia bilunaris, Fragilaria capucina and Gomphonema angustatum. On the other hand, the highly polluted downstream sites were characterized by Gomphonema parvulum, Nitzschia palea, Pinnularia amazonica and Synedra ulna. Species diversity and richness differed between the substrates, tending to be high on natural compared artificial substrate. Indicator species analysis showed that common diatom species were not restricted to single substrate. However, some species tended to prefer certain substrates as suggested by their highest indicator values in these preferred substrates. Specificity was generally high for natural compared to artificial substrates. Among the artificial substrates, more species tended to prefer glasses compared to bricks. Pollution tolerant species, N. palea, G. parvulum and Achnanthidium minutissimum, were highly associated with artificial substrates. Substrate differences may affect the interpretation of water quality results because the absence of a particular species on a given site is can be mistaken for the effects of the perturbations under study. The use of natural substrate is recommended compared to artificial substrate given the advantages of the former compared to the latter.
\end{abstract}

Keywords: artificial substrate; indicator values; species diversity; streams; water quality assessment

\section{INTRODUCTION}

Multiple factors prevailing at different temporal and spatial scales play an important role in structuring benthic diatom communities in lotic systems (Potapova \& Charles 2002; Moura et al., 2007), with local environmental conditions playing a more important role compared to broad-scale climatic, vegetational and geographical factors (Pan et al., 1996). Each particular species requires different structural, physical and chemical characteristics intrinsic to its habitat. Whenever these characteristics are subject to variations, niche composition is affected. Species vary in their sensitivity and those more resistant to environmental changes, caused either by natural fluctuations or human activities, may be favoured by selection (Rocha, 1992). Changes in any of these factors need not necessarily bring about the death of some algal species so long as the changes remain within the limits of tolerance of the species. On the contrary, these changes will inhibit the multiplication of some of the species originally present, and encourage that of others, so that primarily the association, that is the percentage composition and not the flora as such, will be changed (Pan et al., 1996).

Diatom assemblages in lotic ecosystems provide a direct, holistic and integrated measure of the integrity of these systems. Two major approaches to the use of diatoms for assessment of the ecological integrity of lotic systems are generally used worldwide. The first approach involves direct sampling of natural substrate - the favourite being epiliton, while the second approach involves sampling of artificial substrate placed in water - the favourite being glass (Round, 1991).

Direct sampling of natural substrate has no a priori recommendations and has several advantages (Descy \& Coste, 1991; Leclercq \& Manquet, 1987). However, direct sampling has the following disadvantages: 1) in silted lowland rivers stones are often thickly coated with silt that modifies or eliminate the eplithic flora; 2 ) it is not always easy to sample concrete and bad rock; 3 ) in 


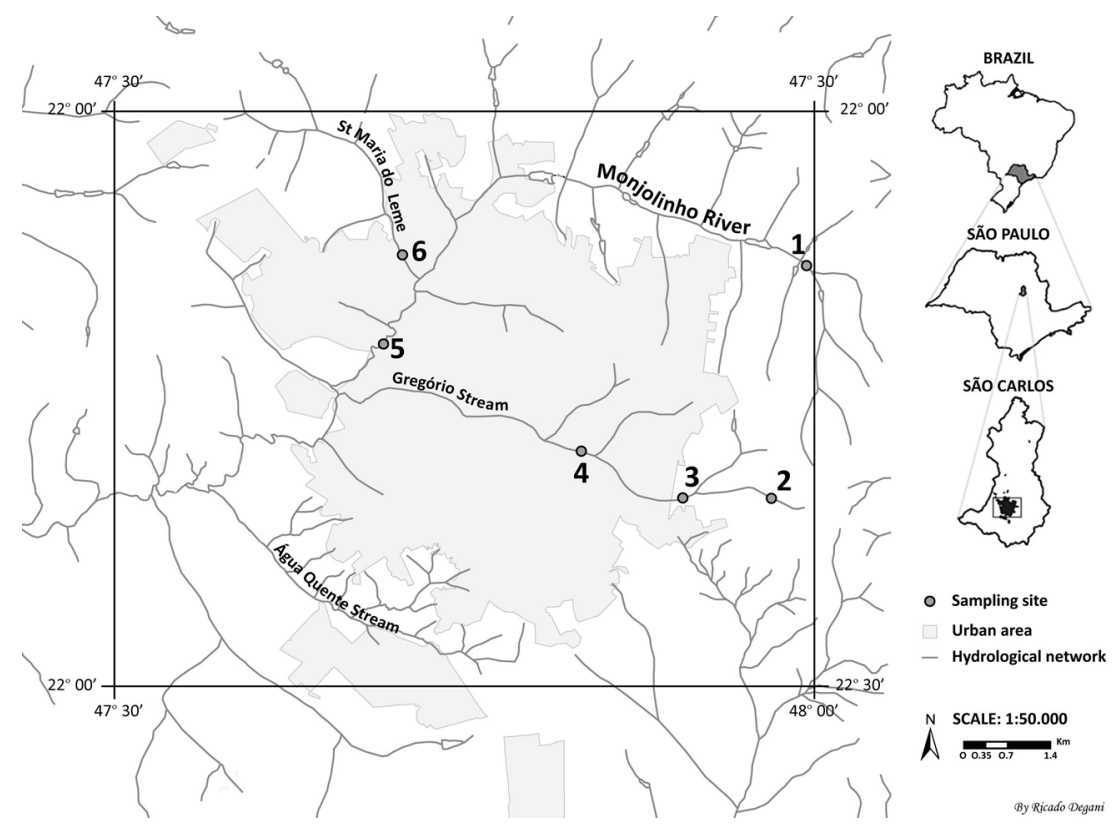

Figure 1 - The location of the sampling sites in the study area.

torrential upper stretches sampling can be difficult and often the flora is depleted; and 4) shading by surrounding vegetation reduces species richness and biomass (Round, 1991). Diversity and productivity of diatoms vary from one rock type to another depending on the nature of the physical and chemical properties of the rock. Large stones are expected to have stable communities, whilst small ones may be so moved during periods of high flow that the flora diversity and richness is reduced (Marker \& Willoughby, 1988). A careful consideration of these factors during sample collection and subsequent data interpretation is, therefore, necessary as ignoring them is likely to lead to biased results.

The challenges posed by direct sampling in the assessment of biotic integrity of lotic systems can be circumvented by use of artificial substrate, traditionally favourable being glass slides and in some case bricks are also used. The artificial substrate has the advantage that flora can be observed directly, substratum is standard at all sampling sites and time of exposure can be controlled (Round, 1991). However, the disadvantages are overwhelming (Descy \& Coste, 1991): 1) require apparatus to be fixed in the river and there are often loses; 2) there is need to experiment to obtain the optimum time of exposure and often 4 or even 8 weeks is necessary, preventing a rapid estimation of water quality such as can be obtained within hours of sampling the epiliton directly; 4) the flora is an artificial assemblage selected by smooth slide and perhaps by differences due to positioning of slides in relation to the currents; 5) the smooth surface often results in sloughing of the community; and 6) random sampling is not allowed.

Studies on the periphytic community are scarce in the study area. Our comprehension of the role of environmental factors in shaping these communities and its subsequent effects on diatom based water quality is thus still in its infancy. The main purpose of this study was to describe diatom species associations in relation to environmental variables in the system using natural and artificial substrates. The study of periphytic community on artificial substrate (glass) carried out in other systems (Arroio Sampaio and its tributaries (Oliveira et al., 2001)) showed that diatom groups were more representative of the community in this system considering species richness and abundance; hence we employed the same technique in the study area. Specifically the study aimed at: 1) comparing the development of benthic diatom communities on two artificial substrates (glass or bricks) relative to natural substrate; 2) assessing the suitability of artificial substrates compared to natural substrates for diatombased water quality assessment; and 3) assessing the importance of environmental variables in structuring benthic diatom communities.

\section{MATERIALS AND METHODS}

\section{Study area}

The area under study is shown in Figure 1. Headwaters of the study system (Monjolinho River and its tributaries, Gregório and Maria Madalena) fall within mainly agricultural area. From agricultural area, the streams pass through urban area of the city of São Carlos, which covers a total area of $1143.9 \mathrm{~km}^{2}$. The area is characterized by rugged topography and an average annual temperature around $19.5^{\circ} \mathrm{C}$, with mean monthly maximum around $21.9^{\circ} \mathrm{C}$ recorded in January 
and February, and the mean monthly minimum around $15.9^{\circ} \mathrm{C}$ recorded in July.

In 2008, the population of São Carlos was estimated at 218080 inhabitants (IBGE, 2008). Now, the expansion of the city does not meet the technical standards that go with it in terms of sewage treatment, collection of garbage, urban drainage and other aspects. Streams in the study area, therefore, receive untreated or partially treated effluent from various domestic and industrial sources as well as other diffuse sources as they pass through the city. This results in stream health deterioration, loss of the remaining primary vegetation and eutrophication, among other problems.

Six sites were established in three stream systems; 3 sites in the relatively less impacted headwaters to act as references, and 3 sites in the urban area. Sites 1 and 5 were located along Monjolinho River; sites 2, 3 and 4 were located along Gregório stream; site 6 was located along Maria Madalena stream. The rationale for selecting the sampling sites was to obtain a pollution gradient, from relatively unpolluted headwaters to highly polluted downstream sites.

\section{Data collection}

Diatom and water quality sampling was done during dry season when flow was stable (September to October 2008) at the 6 sites. Dry season was selected to avoid variable effects of rainy season, such as variations in water level and velocity, which affect diatom development, especially growth rate and relative abundance of different species (Duong et al., 2006). At each site, dissolved oxygen (DO), electrical conductivity, temperature, $\mathrm{pH}$, concentration of total dissolved solids (TDS), and turbidity were measured using a Horiba U23 and W-23XD Water Quality Meter (Horiba Ltd, Japan). The depth and current velocity were relatively uniform among the sites $\left(10-30 \mathrm{~cm}\right.$ and $1.5-2.0 \mathrm{~ms}^{-1}$ respectively). The percentage riparian vegetation cover was estimated at each site. Altitude was determined using a GPS (Northport Systems, Inc. Toronto, Canada). Light intensity was measured using LI-193 Spherical Quantum Sensor (LI-COR Worldwide, Brazil).

Water samples for total nitrogen (TN) and total phosphorus (TP) analysis were also collected at each site using acid-cleaned polyethylene containers (Valderrama, 1981). Water samples for biochemical oxygen demand $\left(\mathrm{BOD}_{5}\right)$ and chemical oxygen demand (COD) were collected following Apha (1988). All the physical and chemical characteristics that vary with time were measured twice, on 16 September when the artificial substrates were placed at the different sites and on 21 October when the artificial substrate was sampled.

At each site 2 bricks measuring $10 \times 21 \mathrm{~cm}$ (total area $=420 \mathrm{~cm}^{2}$ ) and 4 rugose glass slides measuring
$7 \times 17 \mathrm{~cm}$ (total area $=714 \mathrm{~cm}^{2}$ ), as artificial substrate for algal attachment, were immersed in the water column, parallel to the current at a depth of 20 to $30 \mathrm{~cm}$ below the surface. These substrates were left for 4 weeks, which is the recommended colonization time of periphyton (Round, 1991; Descy \& Coste, 1991). On sampling, the material were carefully brought to the surface and thoroughly rinsed with filtered river water. Biofilms were collected by brushing the material with a toothbrush. The resulting suspensions from the replicates were pooled and sub-samples were used in the subsequent procedures.

Epipelic diatoms were sampled at the time of sampling of artificial substrates by pressing a Petri dish lid $\left(\right.$ area $\left.=17 \mathrm{~cm}^{2}\right)$ into the top layer of silt/clay to a depth of $5-7 \mathrm{~mm}$ followed by sliding a spatula blade under the Petri dish to isolate the contents in the dish, which were then gently brought to the surfaces. The contents were then emptied into a labelled container. Samples from 6 locations in each sampling were pooled into a single sample; the total area sampled was 102 $\mathrm{cm}^{2}$. Epipelic diatoms were sampled instead of the commonly used epilithic diatoms in water quality assessment because stones ware not present at some sites.

\section{Laboratory analysis}

Sub-samples of the diatom suspensions were cleaned of organic material using wet combustion with concentrated sulphuric acid and mounted in Naphrax (Northern Biological supplies Ltd. UK. RI = 1.74) following Biggs \& Kilroy (2000). Three replicate slides were prepared for each sample. A total of 500-600 frustules per sample (depending on the abundance of diatoms) were identified and counted using the phase contrast light microscope (1000 X). The diatoms were identified to species level based on studies by Mizuno 1964; Patrick \& Reimer 1966a, b; Bourrelly 1981; Lobo et al., 1996; John, 2000; Biggs \& Kilroy 2000; Oliveira et al., 2001; Lobo et al., 2002; Lobo et al., 2004; Bicudo \& Menezes 2006; Salomoni et al., 2006; Delgado et al., 2007; Moura et al., 2007; Soares et al., 2007; Zalocar de Damitrovic et al., 2007 and the website of the Phycology Section of The Academy of Natural Sciences of the USA (http://diatom.acnatsci.org).

The concentration of TN and TP in the water samples was determined following the method by Golterman et al. (1978) and Valderrama (1981) respectively. $\mathrm{BOD}_{5}$ was determined by filling with water samples from all sites, to overflowing, airtight bottles of known size and incubating them at $25^{\circ} \mathrm{C}$ for 5 days. DO was measured initially and after incubation following Winkler Method, the $\mathrm{BOD}_{5}$ was computed from the difference between initial and final DO following Apha (1988). COD was determined by oxidation of organic 
matter by boiling water samples in mixture of chromic and sulphuric acids following Apha (1988).

\section{Data analysis}

Species richness $(S)$, Shannon's diversity $(H)$ and equitability $(E)$ indices calculated according to the Shannon (1946) were used as measures of community structure. The IndVal method (Dufrêne \& Legendre 1997) was used to find indicator species and species assemblages characterizing the three substrates. This method combines a species' relative abundance with its relative frequency of occurrence in the various substrates. Indicator species are defined as the most characteristic species of each substrate, found mostly in a single substrate and present in the majority of those substrates. For each species $i$ in each substrate type $j$, we computed the product of $\mathbf{A}_{i j}$, the mean abundance of species $i$ in the substrate type $j$ compared to all substrate studied (specificity), by $\mathbf{B}_{i j}$, the relative frequency of occurrence of species $i$ in the substrate type $j$ (fidelity), according to the formula modified from Dufrêne \& Legendre (1997) as follows:

$$
\begin{aligned}
& \mathrm{A}_{i j}=\mathbf{N}_{i j} / \mathbf{N}_{i} \\
& \mathrm{~B}_{i j}=\mathrm{NS}_{i j} / \mathrm{NS} \\
& \text { IndVal }{ }_{i j}=\mathrm{A}_{i j}{ }^{*} \mathrm{~B}_{i j}{ }^{*} 100
\end{aligned}
$$

where IndVal ${ }_{i j}=$ Indicator Value of species $i$ in substrate type $j, \mathbf{N}_{i j}=$ mean number of individuals of species $i$ across substrate type $j, \mathbf{N}_{i}=$ sum of the mean number of individuals of species $i$ over all substrates, $\mathrm{NS}_{i j}=$ the number of substrates $j$ where species $i$ is present, $\mathbf{N S}_{j}=$ the total number of substrates.

Multivariate data analyses were performed on the diatom data set to explore the main gradients of floristic variation and to detect and visualize similarities in diatom samples. Detrended correspondence analysis (DCA) was applied on diatom data set to determine the length of the gradient (Hill and Guach 1980). DCA revealed that the gradient was greater than 3 standard deviation units (3.9); therefore, unimodial ordination techniques would be more appropriate. Canonical correspondence analyses (CCA), was performed to relate diatom community structure to simultaneous effects of environmental variables and to explore the relationship among and between species and these predictor variables (ter Braak \& Verdonschot, 1995). Preliminary CCA identified collinear variables and selected a subset on inspection of variance inflation factors $(\mathrm{VIF}<20$; ter Braak \& Smilauer, 2002). Exploratory variables were subjected to step wise forward selection procedure in which the statistical significance of each variable was tested by the Monte Carlo permutation test (999 unrestricted permutations, $p d " 0.05$ ). CCA and DCA were performed using PAlaeontological STatistics (PAST) software version 1.95 (Hammer et al. 2009).

\section{RESULTS}

\section{Physical and chemical characteristics of water}

The values of physical and chemical variables measured in the study area during the study period are shown in Table 1. The water quality generally tended to deteriorate downstream as the streams passed through the urban area due to discharge of treated and untreated domestic and industrial effluent, as well as other diffuse sources of pollution from the city. The $\mathrm{pH}$ increased slightly down the agricultural to urban gradient being slightly acidic at upstream sites and slightly alkaline/ neutral at downstream sites. Temperature, conductivity, turbidity, TDS, stream width and light intensity tended to increase downstream while dissolve oxygen, altitude and percentage canopy cover tended to decrease downstream.

The concentration of TN and TP in the water samples showed a general tendency of increasing along agricultural to urban gradient (Table 1 ) due to domestic and industrial pollution. The levels $\mathrm{BOD}_{5}$ and $\mathrm{COD}$ also followed a broadly similar pattern to that of nutrient levels tending to be generally low in agricultural sites and increasing downstream due to domestic and industrial pollution (Table 1).

Table 1 - The mean values of physical and chemical variables measured on all the sites at the placing and collection of artificial substrate.

\begin{tabular}{lcccccc}
\hline \hline Site & $\mathbf{1}$ & $\mathbf{2}$ & $\mathbf{3}$ & $\mathbf{4}$ & $\mathbf{5}$ & $\mathbf{6}$ \\
\hline Temperature $\left({ }^{\circ} \mathrm{C}\right)$ & 18.3 & 20.9 & 20.6 & 21.2 & 20.39 & 24.8 \\
Conductivity $\left(\mu \mathrm{S} \mathrm{cm} \mathrm{cm}^{-1}\right)$ & 45.0 & 20.0 & 53.0 & 89.0 & 30.0 & 715.0 \\
TN $\left(\mathrm{mg} \mathrm{L}^{-1}\right)$ & 0.65 & 0.18 & 0.24 & 1.29 & 0.93 & 38.32 \\
TP $\left(\mathrm{mg} \mathrm{L}^{-1}\right)$ & 0.01 & 0.01 & 0.01 & 0.16 & 0.02 & 2.97 \\
DO $\left(\mathrm{mg} \mathrm{L}^{-1}\right)$ & 7.3 & 8.2 & 7.6 & 6.9 & 7.2 & 1.9 \\
BOD5 $\left(\mathrm{mg} \mathrm{L}^{-1}\right)$ & 0.9 & 1.0 & 2.6 & 6.9 & 7.2 & 19.5 \\
pH & 6.6 & 6.4 & 6.3 & 6.8 & 6.8 & 7.2 \\
Turbidity $(\mathrm{NTU})$ & 0.0 & 0.0 & 0.0 & 0.0 & 0.0 & 0.1 \\
TDS $(\mathrm{g} \mathrm{L}-1)$ & 29.4 & 13.4 & 22.6 & 57.4 & 19.3 & 457.8 \\
Altitude $(\mathrm{m})$ & 761.0 & 837.0 & 831.0 & 794.0 & 761.0 & 724.0 \\
Canopy cover $(\%)$ & 80.0 & 95.0 & 60.0 & 50.0 & 45.0 & 20.0 \\
Light intensity $\left(\mu \mathrm{mol} \mathrm{s} \mathrm{s}^{-1} \mathrm{~m}^{-2}\right)$ & 105.0 & 327.0 & 431.0 & 1500.0 & 649.0 & 1780.0 \\
Mean width $(\mathrm{m})$ & 0.6 & 0.8 & 1.1 & 1.9 & 1.0 & 12.5 \\
\hline \hline
\end{tabular}


Table 2 - Species richness $(S)$, diversity $(H)$ and evenness indices $(E)$ for the sites and substrates sampled (E, epipelion; B, bricks; GL, glass).

\begin{tabular}{|c|c|c|c|c|c|c|c|c|c|c|c|c|c|c|c|c|c|}
\hline Site & \multicolumn{3}{|c|}{1} & \multicolumn{3}{|c|}{2} & \multicolumn{3}{|c|}{3} & \multicolumn{3}{|c|}{4} & \multicolumn{3}{|c|}{5} & \multicolumn{2}{|c|}{6} \\
\hline Substrate & $E$ & B & G & $E$ & B & G & $E$ & B & G & $E$ & B & $\mathbf{G}$ & $E$ & B & G & $E$ & G \\
\hline$H^{\prime}$ & 3.21 & 2.42 & 2.81 & 3.15 & 2.72 & 2.96 & 3.09 & 2.92 & 2.85 & 2.68 & 2.10 & 2.27 & 2.39 & 1.94 & 2.12 & 1.70 & 1.52 \\
\hline$E$ & 0.89 & 0.77 & 0.84 & 0.90 & 0.89 & 0.85 & 0.92 & 0.86 & 0.90 & 0.93 & 0.91 & 0.82 & 0.75 & 0.66 & 0.85 & 0.93 & 0.81 \\
\hline$S$ & 63 & 34 & 40 & 47 & 23 & 45 & 48 & 39 & 27 & 31 & 11 & 23 & 30 & 26 & 20 & 25 & 19 \\
\hline
\end{tabular}

\section{Diatom distribution}

A total of 112 diatom species belonging to 44 genera that are distributed among the families Achnanthidiaceae, Achnanthaceae, Bacillariaceae, Eunotiaceae, Cymbellaceae, Gomphonemataceae, Fragilariaceae, Melosiraceae, Naviculaceae, Rhoicospheniaceae, Rhopalodiaceae and Surirellaceae were recorded in all the diatom samples collected. Among the 112 species observed, 53 species (Table 3 ) were considered as mostly frequent in the study area (e" 10 cells $/ \mathrm{cm}^{2}$ occurrence and present in at least 2 samples).

Species richness, diversity and equitability tended to be higher in relatively unpolluted sites $(1,2$, $3)$ compared to the polluted sites $(4,5$ and 6$)$ being highest at site 1 and lowest at site 4 (Table 2). Species diversity and richness tended to be high on glass compared to bricks. Species diversity and richness were generally high on natural substrate compared to artificial ones.

Indicator species analysis showed that common diatom species were not restricted to single substrate (Table 3). Indicator values can vary from $0 \%$ for a taxon that has the same occurrence and abundance in all the groups of substrates to $100 \%$ for a taxon that is confined to one group of substrate. However, some species tended to prefer certain substrates as indicated by their highest indicator values in these preferred substrates. Specificity was generally high for natural compared to artificial substrates. Among the artificial substrates, more species tended to prefer glasses compared to bricks.

Nitzschia palea (Kützing) Smith, and Gomphonema parvulum (Kützing) Cleve commonly reported to be resistant to organic and heavy metal pollution and have been frequently recorded in waters that are nutrient rich and poorly oxygenated (Round 1991; Biggs \& Kilroy 2000; Potapova \& Charles 2003; Duong et al., 2006), were highly associated with artificial substrates. Achnanthidium minutissimum, also commonly considered a disturbance-tolerant species (Stevenson \& Bahls 1999) was highly associated with the artificial substrate.

The results of CCA are presented in Figure 2. Only 5 variables, $\mathrm{pH}, \mathrm{TP}, \mathrm{DO}, \mathrm{BOD}_{5}$ and percentage canopy cover were used in the analysis. The first and second axes of CCA explained $22.6 \%$ of the proportion of the diatom species variance; CCA axis 1 , eigenvalue $=0.38$ and axis 2, eigenvalue $=0.25$. Monte Carlo unrestricted permutation test indicated that axis 1 (99 permutations) and axis 2 (99 permutations of axis 2 with axis 1 as a covariable) were statistically significant ( $p d " 0.05)$. CCA axis 1 and 2 roughly separated relatively

Figure 2 - Canonical correspondence analysis (CCA) diagram showing environmental variables and diatom species in the ordination space of the first and second axes. Environmental variables that had low correlations with ordination axes are not shown. Species codes correspond to those in Table 3, E, epipelion; G, glass and B, bricks.

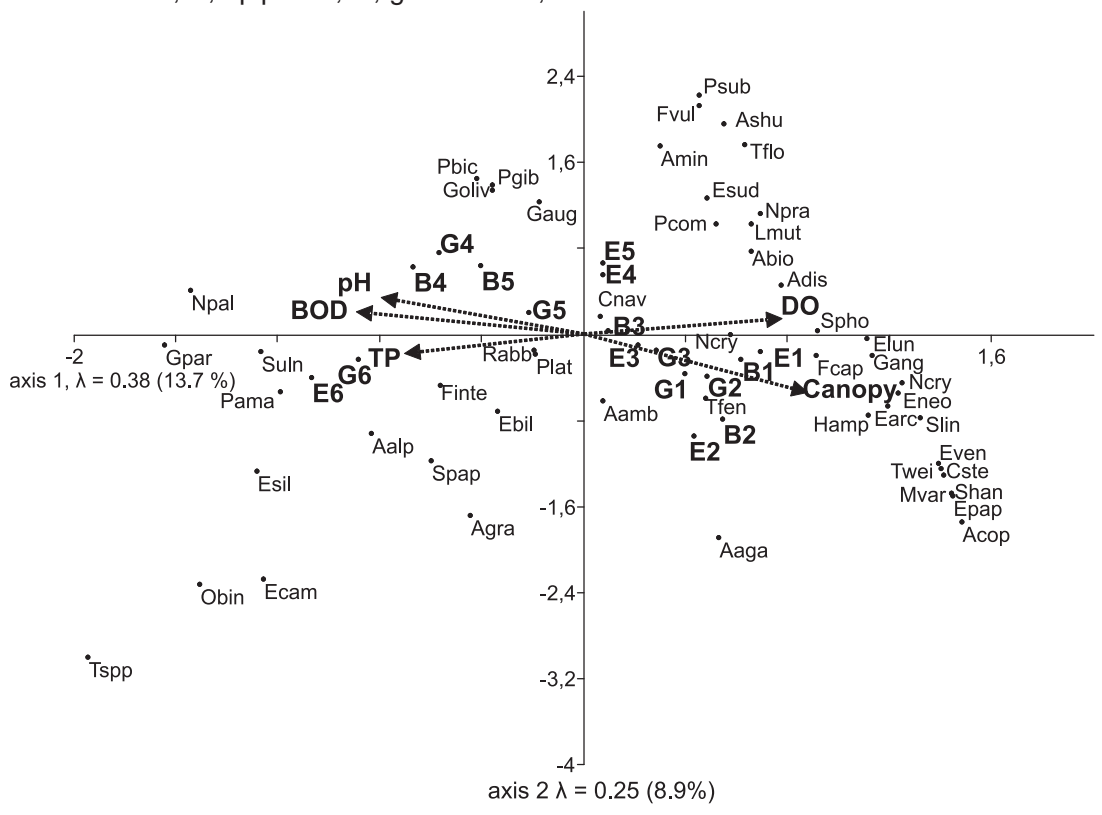


Table 3 - Indicator species and species assemblages characterizing the three substrates based on the most frequently occurring diatom. Species with the highest indicator values (\%) in the different substrates are highlighted.

\begin{tabular}{|c|c|c|c|c|}
\hline \multirow[b]{2}{*}{ Species } & \multirow[b]{2}{*}{ Code } & \multicolumn{3}{|c|}{ Indicator values (\%) } \\
\hline & & Epipelion & Brick & Glass \\
\hline Achnanthidium biosolettianumGrunow & Abio & 58.1 & 13.9 & 28.0 \\
\hline Achnanthidium minutissimum(Kützing) Czarnecki & Amin & 7.7 & 33.0 & 59.3 \\
\hline Amphora copulate(Kützing) Schoeman and Archibald & Acop & 59.1 & 7.6 & 0.0 \\
\hline Encyonopsis schubartii(Hustedt) Krammer & Ashu & 0.0 & 28.4 & 38.3 \\
\hline Aulacoseira agassizii(Ostenf) Simonsen & Aaga & 15.4 & 65.2 & 19.4 \\
\hline Aulacoseira alpigena(Grunow) Krammer & Aalp & 33.9 & 36.7 & 29.4 \\
\hline Aulacoseira ambigua(Grunow) Simonsen & Aamb & 21.6 & 21.5 & 56.9 \\
\hline Aulacoseira distans(Ehrenberg) Simonsen & Adis & 26.4 & 26.6 & 47.0 \\
\hline Aulacoseira granulate(Ehrenberg) Simonsen & Agra & 60.8 & 23.8 & 15.4 \\
\hline Cyclotella pseudostelligeraHustedt & Cpse & 53.3 & 0.0 & 13.4 \\
\hline Cyclotella stelligera(Cleve and Grunow) Van Heurck & Cste & 52.5 & 0.0 & 14.2 \\
\hline Cymbopleura naviculiformis(Auerswald) Krammer & Cnav & 52.4 & 16.4 & 31.2 \\
\hline Encyonema neomesianumKrammer & Eneo & 28.5 & 50.5 & 20.9 \\
\hline Encyonema silesiacum(Bleisch) Mann & Esil & 45.0 & 24.9 & 30.1 \\
\hline Eunotia arcusEhrenburg & Earc & 19.3 & 46.8 & 33.9 \\
\hline Eunotia bilunaris(Ehrenberg) Mills & Ebil & 42.3 & 17.4 & 40.4 \\
\hline Eunotia camelusEhrernberg & Ecam & 24.3 & 16.8 & 58.8 \\
\hline Eunotia lunaris(Ehrenberg) Grunow & Elun & 14.9 & 52.5 & 32.6 \\
\hline Eunotia papilla(Ehrenberg) Hustedt & Epap & 36.1 & 19.1 & 11.4 \\
\hline Eunotia sudetica Müller & Esud & 56.0 & 0.0 & 10.6 \\
\hline Eunotoa veneris(Kützing) de Toni & Even & 14.6 & 74.0 & 11.3 \\
\hline Fragilaria capucinaDesmaziéres & Fcap & 5.2 & 54.2 & 40.6 \\
\hline Fragilaria intermediaGrunow & Finte & 18.6 & 50.8 & 30.6 \\
\hline Frustulia vulgaris(Thwaites) De Toni & Fvul & 50.8 & 32.4 & 16.9 \\
\hline Gomphonema angustatum(Kützing) Rabenhorst & Gang & 17.2 & 44.2 & 38.6 \\
\hline Gomphonema augur(Ehrenberg) LangeBertalot & Gaug & 4.0 & 37.9 & 58.1 \\
\hline Gomphonema olivaceum(Lyngbye) Kützing & Goliv & 4.9 & 43.9 & 51.2 \\
\hline Gomphonema parvulum(Kützing.) Cleve & Gpar & 21.3 & 32.8 & 45.9 \\
\hline Hantzschia amphioxys (Ehrenberg) Grunow & Hamp & 58.6 & 0.0 & 8.1 \\
\hline Luticola mutica(Kützing) Mann & Lmut & 51.7 & 0.0 & 15.0 \\
\hline Melosira variansAgardh & Mvar & 54.4 & 0.0 & 12.2 \\
\hline Navicula cryptocephala(Grunow) Cleve, & Ncry & 41.3 & 15.4 & 43.4 \\
\hline Navicula cryptotenellaLange-Bertalot & Ncry & 8.9 & 37.5 & 53.6 \\
\hline Nitzschia palea (Kützing) Smith & Npal & 30.2 & 32.9 & 36.9 \\
\hline Nupela praecipua(Reichardt) Reichardt & Npra & 90.8 & 6.5 & 2.7 \\
\hline Oxyheis binalis & Obin & 39.1 & 14.5 & 46.4 \\
\hline Pinnularia amazonicaMetzeltin and LangeBertalot & Pama & 13.5 & 17.4 & 69.1 \\
\hline Pinnularia biceps Patrick and Reimer & Pbic & 0.0 & 43.1 & 56.9 \\
\hline Pinnularia gibba(Ehrenberg) Grunow & Pgib & 41.3 & 40.3 & 18.4 \\
\hline Pinnularia lata (Brébisson) Smith & Plat & 16.2 & 13.1 & 70.7 \\
\hline Pleurosigma compactum Greville & Pcom & 56.8 & 18.3 & 24.8 \\
\hline Psammothidium subatomoides(Hustedt) Bukhtiyarova & Psub & 0.0 & 0.0 & 33.3 \\
\hline Rhoicosphenia abbreviata(Agardh) LangeBertalot, & Rabb & 73.2 & 5.5 & 21.3 \\
\hline Sellaphora pupula(Kützing) Mereschkowsky & Spap & 80.0 & 16.7 & 3.3 \\
\hline Stauroneis phoenicenteron(Ehrenberg) Hustedt & Spho & 69.4 & 20.3 & 10.3 \\
\hline Stephanodiscus hantzschiiGrunow & Shan & 0.0 & 55.0 & 11.7 \\
\hline Surirella linearis Smith & Slin & 0.0 & 36.8 & 29.9 \\
\hline Ulnaria ulna(Nitzsch) Compère & Suln & 78.7 & 5.9 & 15.4 \\
\hline Thalassiosiraspp & Tspp & 0.0 & 28.2 & 38.5 \\
\hline $\begin{array}{l}\text { Thalassiosira weissflogii(Grunow) Fryxell and Hasle } \\
\text { Total number of species with highest indicator }\end{array}$ & Twei & 33.3 & 0.0 & 0.0 \\
\hline values & & 23 & 12 & 17 \\
\hline
\end{tabular}

less polluted sites $(1,2$ and 3$)$ on the right of the first axis from polluted sites $(4,5$ and 6$)$ at the left of the first axis. An exception to this was epipelion substrate for sites 4 and 5 that were placed in the former group instead of the expected later polluted later group. The first group of sites was associated with high $\mathrm{DO}$, low $\mathrm{BOD}_{5}$, high canopy cover (which was highly negatively correlated to temperature, light intensity and mean stream width), low turbidity, slightly acidic $\mathrm{pH}$ and low TP (which was highly positively correlated with TDS, TN, and conductivity) while the second group of sites was associated with low $\mathrm{DO}$, high $\mathrm{BOD}_{5}$, low canopy cover, high turbidity, slightly neutral $\mathrm{pH}$ and high TP.

The upstream, relatively less polluted, sites $(1,2$ and 3 ) were characterized by such species as
Aulacoseira ambigua (Grunow) Simonsen, Aulacoseira granulata (Ehrenberg) Simonsen, Cymbopleura naviculiformis (Auerswald) Krammer, Eunotia bilunaris (Ehrenberg) Mills, Fragilaria capucina Desmaziéres, and Gomphonema angustatum (Kützing) Rabenhorst. These species were highly positively associated with CCA axis 1. On the other hand, downstream, highly polluted, sites $(4,5$ and 6$)$ were characterized by $G$. parvulum, $N$. palea, Pinnularia amazonica Metzeltin and LangeBertalot and Ulnaria ulna (Nitzsch) Compère (negatively related to CCA axis 1) which have been reported to be highly pollution tolerant (Round 1991; Biggs \& Kilroy 2000; Potapova \& Charles 2003; Duong et al., 2006). 


\section{DISCUSSION}

Based on organic pollution, eutrophication and other environmental variables, a gradient along the streams from agricultural to urban area characterised by oligotrophic, low organic pollution, high altitude and high percentage canopy cover upstream sites, and eutrophic, high organic pollution, low altitude and low percentage cover downstream sites were observed. This pollution gradient and environmental variables determine the overall benthic diatom communities. The ecological niche of a taxon is determined by a combination of these factors along with its competitive ability (Kelly \& Whitton, 1995).

Diatom community structure closely followed the pollution increase gradient with species richness, diversity and equitability generally differing among sampling sites, tending to be higher in relatively unpolluted compared to polluted sites. As pollution increased, low pollution tolerant species such as $A$. ambigua, A. granulate, $C$. naviculiformis, E. bilunaris, $F$. capucina, and $G$. angustatum were replaced by pollution tolerant species such as G. parvulum, N. palea, and $S$. ulna. The tolerant species has been reported to be associated with waters of relatively high ionic strength and high conductivity, and is known to be resistant to organic and heavy metal pollution (Round, 1991; Biggs \& Kilroy, 2000; Potapova \& Charles, 2003; Duong et al., 2006). These species have also been frequently recorded in waters that are nutrient rich and poorly oxygenated (Round, 1991). Lange-Bertalot (1979) stated that species are indicative of the upper limits of pollution that they can tolerate and not the lower limit. Thus, species that develop well in polluted zones (e.g. G. parvulum, $N$. palea, $P$. amazonica and $S$. ulna in this case) may also occur in clean water. Their value as indicators is their presence in polluted water.

\section{A comparison of artificial and natural substrate}

The flora of artificial substrates is an artificial assemblage selected by physical and chemical properties of the substrate (e.g. texture, chemical composition) and perhaps positioning of substrate in relation to the currents. The smooth surface of glass slides, for example, often results in sloughing of the community (Descy \& Coste, 1991); the species found on the glass substrate were mostly tightly attached ones.

Each species has specific microhabitat requirements (Round, 1991) and these requirements in most cases are not met by artificial substrate limiting the number of species that can grow on these substrates. This affects the interpretation of water quality management results as the absence of a particular species on a given site is likely to be mistaken for the effects of the perturbations under study. For example, epipelion substrate for sites 4 and 5 were grouped together with relatively less polluted sites while artificial substrates from these sites were classified as polluted (Figure 2). The separation is due to differences in community structure between the artificial and natural substrate, which in turn is due to differences in physical and chemical properties of the substrate and has nothing to do with water quality as the substrates were sampled from the same sites.

Komarek \& Sukacova (2004) have shown that diatom communities is indicative of more successional processes than water quality often characterized by introduced artificial substrates. They recommend leaving artificial substrate for a year before sampling to allow the diatom communities to progress from a colonization community to a stable community reflecting environmental conditions and typical of natural communities. This prevents rapid estimation of water quality, such as can be obtained within hours of direct sampling of epipelion.

Besides, use of artificial substrate requires apparatus to be fixed in the river and there are often losses (e.g. loss of bricks in this study at site 6), and random sampling is not possible (Round, 1991; Descy \& Coste, 1991). This further complicates the use of artificial substrate for water quality management. We therefore recommend the sampling of natural substrate compared to artificial substrate provided the same microhabitat type is available at all the sites to be assessed.

Species diversity, richness and equitability were high on glass compared to bricks. More species had highest indicator values on glass substrate compared to bricks. This could be due to differences in physical and chemical attributes of the two substrates. This also affects the interpretation of water quality management results as the absence of a particular species on a given site is likely to be mistaken for the effects of the perturbations under study. From our results, we recommend that water quality assessment based on species diversity from artificial substrates should consider using glass instead of bricks. However, care should be taken in the use of rugose glass slides as smooth surface of glass slides often results in sloughing of the community (Descy \& Coste, 1991), thus affecting water management results.

\section{Relationship with environmental variables}

Organic pollution, eutrophication, $\mathrm{pH}$ and percentage canopy cover were the major drives of diatom community structure in this study. Environmental monitoring studies in Southern Brazil (Lobo et al., 1996; Oliveira 2001; Lobo et al., 2004; Salomoni et al., 2006) showed that diatom communities in lotic ecosystems 
are a result of the interaction of variables characterising the process of organic contamination as well as eutrophication. Lobo et al. (2004) classified benthic diatom species into 5 groups based on tolerance to organic pollution and eutrophication using TWINSPAN results leading to the development of the first Brazilianbased water quality index, Biological Index of Water Quality (BIWQ) trophic index. Eight of these species, E. silesiacum, F. capucina, G. angustatum, M. varians, N. cryptotenella, N. palea, G. parvulum and $A$. minitissimum, were collected in this study. The distribution of these species generally seemed to agree with their classification except for that of $F$. capucina that they classified as highly tolerant of eutrophication, but in this study, they seemed to be favoured in less polluted sites. However, this species has been described as having broad eutrophication tolerance ranges, occurring successfully from oligotrophic to eutrophic environments (Van Dam et al., 1994).

Lobo et al. (2004) described N. palea as partially pollution tolerant. In this study, however, this species had high relative abundance in eutrophic sites 4, 5 and 6. Many studies describe N. palea and G. parvulum as cosmopolitan, high pollution tolerant species, especially eutrophication and organic pollution (e.g. Lange-Bertalot, 1979; Kobayasi \& Mayama, 1989; Tapia, 2008) and are good indicators of polisaprobic conditions (Lobo et al., 1996). The success of some Nitzschia species in eutrophic conditions has been attributed to obligate nitrogen heterotrophy (Hellebust \& Lewin, 1977; Kilham et al., 1986), which would overcome the problem associated with low $\mathrm{N}$ : $\mathrm{P}$ ratios. Features that may affect a taxon's performance in high pollution environments as observed at sites 4, 5 and 6 in this study also include ability to survive low concentrations of dissolved oxygen and avoidance of settled solids (Kelly \& Whitton, 1995).

Lobo et al. (2002) have considered G. parvulum, the relatively highly abundant species at downstream eutrophic sites with high organic pollution as ámesosaprobic. In streams located in the Municipal District of Mato Leitão (Brazil), Lobo et al. (1999) classified this species as belonging to both ámesosaprobic and polysaprobic environments. In the same streams, Rodrigues \& Lobo (2000) registered the occurrence of this species in moderately polluted, âmesosaprobic waters. In a study carried out in the same area as the current investigation, Souza (2002) encountered this species in oligosaprobic environments. However, in other studies carried out in rivers, Japan Kobayasi \& Mayama (1989) and Lobo et al. (1996) classified G. parvulum as highly tolerant to organic pollution in agreement with the results of the current study. Similarly, Kelly \& Whitton (1995), working in UK rivers described this species as highly tolerant of eutrophication (indicative value $=3$ and sensitivity value
$=5)$ in their calculation of the Trophic Diatom index (TDI). Diverse mophotypes of $G$ parvulum, however, there is the probably of corresponding to different varieties (Morales \& Jasiki 2002), which would explain the variety of responses attributed to this species.

Percentage canopy cover and $\mathrm{pH}$ were also found to be determining diatom community structures. Percentage canopy cover affects light intensity that is important for the process of photosynthesis (Round 1991; Pan et al., 1996; Potapova \& Charles 2002). The relationship between diatoms and $\mathrm{pH}$ is strong because $\mathrm{pH}$ exerts a direct physiological stress on diatoms (Gensemer, 1991), and also strongly influences other water chemistry variables (Stumm \& Morgen, 1981).

\section{CONCLUSION}

Substrate differences may affect the interpretation of water quality results, because the absence of a particular species on a given site can be mistaken for the effects of the perturbations under study. Thus the use of a natural substrate is recommended compared to artificial substrate given the advantages of the former compared to the latter.

\section{ACKNOWLEDGEMENTS}

This study was made possible by the provision of funds from Third World Academy of Science (TWAS) through Conselho Nacional de Desenvolvimento Científico e Tecnológico (CNPq). I am greatly indebted to my supervisor, Professor José Galizia Tundisi, for his critical remarks on earlier drafts of this work. I also wish to thank the Instituto Internacional de Ecologia and staff for their support during the course of this study.

\section{REFERENCES}

Apha, M.A.H (ed). 1988. Standard Methods for the Examination of Water and Waste Water, 20th ed., American Public Health association, Washington, D.C.

Bicudo, C.E.M.; Menezes, M (2006) Gêneros de água de águas continentais do Brazil: chave para identificação e descrições. Rima Editora, São CarlosSP, Brazil.

Biggs, B.J.F. \& Kilroy, C. 2000. Stream priphyton monitoring manual. NIWA, Christchurch, New Zealand.

Bourrelly. P .1981. Les algues d'eau douce: initiation à la systematique. Société Nouvelle des Editions Boubée, Saint-Michel, Paris. 
de la Rey, P.A.; Roux, H., van Rensburgl, L. \& Vosloo, A. 2008. On the use of diatom-based biological monitoring Part 2: A comparison of the response of SASS 5 and diatom indices to water quality and habitat variation. Water SA 34: 61-69.

Delgado, S.M. \& Souza M.G.M. 2007. Diatomoflórula do rio Descoberto-DF e GO, Brazil, Naviculales (Bacillariophyceae): Diploneidineaes e Sellaphorineae. Acta Botanicâ Brazilianse, 21: 767776.

Descy, J.P. \& Coste, M. 1991. A test of methods for assessing water quality based on diatoms. Verhandlungen der Internationalen Vereinigung für theoretische und angewandte Limnologie 24: 21122116.

Dufrêne, M. \& Legendre, P. 1997. Species assemblages and indicator species: the need for a flexible asymmetrical approach. Ecol Mon 67: 345-366.

Duong, T., Coste M.; Feurtet-Mazel, A et al. 2006. Impact of Urban Pollution from the Hanoi Area on Benthic Diatom Communities Collected from the Red, Nhue and Tolich Rivers (Vietnam). Hydrobiologia 563: 201-216.

Gensemer, R.W. 1991. The Effects of $\mathrm{pH}$ and Aluminum on the Growth of the Acidophilic Diatom Asterionella ralfsii var. Americana. Limnol Oceanogr 36: 123-131.

Golterman, H.L.; Clymo R.S. \& Ohnstad, M.A.M. 1978. Methods for Physical and Chemical Analysis of Fresh Waters. IBP Handbook 8. Blackwell Scientific Publication, Oxford.

Hammer, O., Harper, D. A. T. \& Ryan, P. D., 2009: PAST - PAlaeontological STatistics, version 1.90. http:// folk.uio.no/ohammer/past.

Hellebust, J.A. \& Lewim, J. 1977. Heterotrophic nutrition. In: Werner D., (ed) The biology of diatoms. Blackwell Scientific Publications, Oxford.

Hill, M.O. \& Gauch, H.E.J. 1980. Detrended correspondence analysis: an improved ordination technique. Vegetation 42: 47-57.

IBGE - Instituto Brasileiro de Geografia e Estatística. Pesquisa nacional de saneamento básico. . 2008. available at: http://www.ibge.gov.br/home/estatistica/ populacao/

John, J. 2000. Diatom prediction and classification system for urban streams. LWRRDC Canberra.

Kelly, M.G. \& Whitton, B.A. 1995. The trophic diatom index: a new index for monitoring eutrophication in rivers. J Appl Phycol 7: 433-444.

Kilham, P.; Kilham, S.S. \& Hecky, R.E. 1986. Hypothesized resources relationships among African plankton diatoms. Limnol Oceanogr 31: 1169-1181.

Kobayasi H., Mayama S (1982) Most pollution tolerant diatoms of severely polluted rivers in the vicinity of Tokyo. Jap J Phycol 30: 188-196.
Komarek, O. \& Sukacova, K. 2004. The use of artificial substrate in different growth conditions. EkologiaBratilsava, 23: 192-206.

Lange-Bertalot, H. 1979. Pollution tolerance of diatoms as criteria for water quality estimation. Nova Hedwigia 64: 283-304.

Leclerq, L. \& Maquet, B. 1987. Deux nouveaux índices chimique et diatomique de qualite' d'eau courante. Application au Samson et a' ses affluents (bassin de la Meuse belge). Comparaisond índices chimiques, bioce'notiques et diatomiques. Institut Royal des Sciences Naturelles de Belgique, document de travail 28.

Lobo, E.A., Bem, D.A.; Costa, A. \& Kirst, A. 1999. Avaliação da qualidade da água dos arroios Sampaio, Bonito e Grande, Município de Mato Leitão, RS, Brasil, segundo a resolução do CONAMA 20/86. Revista Redes, Santa Cruz do Sul 4: 129-146.

Lobo, E.A.; Callegaro, V.L.; Wetzel, C.E et al. 2004. Water quality study of Condor and Capivara streams, Porto Alegre municipal district, RS, Brazil, using epilithic diatoms biocenoses as bioindicators. Oceanol Hydrobiol Stud Pol 33: 77-93.

Lobo, E.A.; Callegaro, V.L. \& Bender, P. 2002. Utilização de algas diatomáceas epilíticas como indicadoras da qualidade da água em rios e arroios da Região Hidrográfica do Guaíba, RS, Brasil. Santa Cruz do Sul: EDUNISC.

Lobo, E.A.; Callegaro, V.L.M.; Oliveira, M.A et al (1996) Pollution tolerant diatoms from lotic systems in the Jacui Basin, Rio Grande do Sul, Brasil, Iheringia Série Botânica 47: 45 -72.

Lobo, E.A.; Katoh, K.; Aruga, Y. 1995. Response of epilithic diatom assemblages to water pollution in rivers in the Tokyo metropolitan area, Japan. Freshwater Biol 34: 191-204.

Marker, A.F.H. \& Willoughby, L. G. 1988. Epilithic and epiphytic algae in streams of contrasting $\mathrm{pH}$ and hardness. In: Round F.E (ed) Algae and the aquatic environment. Biopress, Briston. pp. 312-325.

Mizuno, T. 1964. Illustrations of freshwater plankton of Japan. Hoikusha, Osaka, Japan: 125-181.

Morales, E.A. \& Jasinski, A. 2002. Morphological studies of Gomphonema parvulum complex: evidence of cryptic species. In $17^{\text {th }}$ International Diatom Syposium, Ottawa, Canada.

Moura, A.N.; Bittencourt-Oliveira, M.C. \& Nascimento, E.C. 2007. Benthic Bacillariophyta of the Paripe River estuary in Pernambuco state, Brazil. Braz J Biol 67: 393-401.

Oliveira, M.A.; Torgan, L.C.; Lobo, E.A et al. 2001. Association of periphytic diatom species of artificial substrate in lotic environments in the Arroio Sampaio basin, RS, Brazil: relationships with abiotic variables. Braz J Biol 6: 523-540. 
Pan, Y.; Stevenson. R.J.; Hill, B.H. et al. 1996. Using diatoms as indicators of ecological conditions in lotic systems: a regional assessment. J N Amer Bethol Soc15: 481-495.

Patrick, R. \& Reimer C.W. 1966\& 1975. The diatoms of the United States. Academy of Natural Sciences, Philadelphia.

Potapova, M. \& Charles, D.F. 2003. Distribution of benthic diatoms in U.S. rivers in relation to conductivity and ionic composition. Freshwater Biol 48: 1311-1328.

Potapova, M.G. \& Charles, D.F. 2002. Benthic diatoms in USA Rivers: distributions along speciation and environmental gradients. J Biogeo 29:167-187.

Rocha, A.A. 1992. Algae as indicators of water pollution. In: Cordeiro-Marino M., Azevedo M.T. P., Sant'anna C.L et al (ed) Algae and environment: a general approach. São Paulo, Sociedade Brasileira de Ficologia, CETESB.

Rodridues, L.M. \& Lobo, E.A. 2000. Analise da estrutura de comunidades de diatomáceas epiliticas no arroio Sampaio, município de Mato Leitão, RS, Brasil. Caderno de pesquisas Serie Botânica Santa Cruz do Sul 12: 5-27.

Round. F.E. 1991. Diatoms in river water-monitoring studies. J Appl Phycol 3: 129-145.

Salomoni, S.E.; Rocha, O.; Callegaro, V.L. \& Lobo, E.A. 2006. Eplithic diatoms as indicators of water quality in the Gravataí river, Rio Grande do Sul, Brazil. Hydrobiologia 559: 233-246.

Shannon, C.E. \& Weaver, W. 1949. The Mathematical Theory of Communication. University of Illinois Press, Urbana.

Soares, M.C.S.; Sophia, M.G. \& Huszar, V.L.M. 2007. Phytoplankton flora of two rivers in Southern BrazilParaibuna and Pomba Rivers, Minas Gerais. Rev Bras Bot 30: 433-450.

Souza, M.G.M. 2002. Variação da comunidade de diatomáceas epiliticas ao longo de um rio impactado no município de São Carlos - SP e sua relação com variáveis fiscas e químicas. Tese (Doutorado e Ciências Biológicas) Ecologia a Recursos Naturais, Universidade Federal de São Carlos, São Carlos SP, Brasil.

Stevenson, RJ. \& Bahls, L.L. 1999. Periphyton protocols. Pages 6/1-6/22 in M. T. Barbour, J. Gerritsen, B. D. Snyder, and J. B. Stribling. Rapid bioassessment protocols for use in streams and wadeable rivers: periphyton, benthic macroinvertebrates, and fish. 2nd edition. EPA 841-B-99-002. Office of Water, US Environmental Protection Agency, Washington, DC.

Stumm, W. \& Morgan, J.J. 1981. Aquatic chemistry: an introduction emphasizing chemical equilibria in natural waters. New York: Wiley-Interscience.

Tapia, P.M. 2008. Diatoms as bioindicators of pollution in the Mantaro River, Central Andes, Peru. Inter J Environ Health 2: 82 - 91.

Ter Braak, C.J.F. \& Verdonschot, P.F.M. 1995. Canonical corespondence analysis and related multivariate methods in aquatic ecology. Aqua Sci 37: 130-137.

Valderrama, J.C. 1981. The simultaneous analysis of total nitrogen and total phosphorus in natural water. Mar Chem 10: 02-122.

Van Dam H., Mertens, A. \& Sinkeldam, J. 1994. A coded checklist and ecological indicator values of freshwater diatoms from the Netherlands. Aquatic Ecol 28: 117133.

Zalocar de Damitrovic, Y.; Poi de Neiff, A.S.G. \& Casco, S.L. (2007) Abundante and diversity of phytoplankton in the Paraná River (Argentina) 220 $\mathrm{km}$ downstream of the Yacyretá reservoir. Braz J Biol 67: 53-63.
Submetido: Agosto/2010 Revisado: Outubro/2010 Aceito: Novembro/2010 